\section{International Scientific Journal Theoretical \& Applied Science}

p-ISSN: 2308-4944 (print)

e-ISSN: 2409-0085 (online)

Year: 2015 Issue: $01 \quad$ Volume: 21

Published: $30.01 .2015 \quad$ http://www.T-Science.org
Sergey Iosifovich Tatarinov

Ph.D. candidate of historical sciences, Associate Professor of Engineering Pedagogy

Educational and Scientific Professional Pedagogical Institute of Ukrainian Engineering and Pedagogical Academy, Ukraine, Donetsk region, Artemovsk tatbronza@yandex.ua

SECTION 13. Geography. History. Oceanology.

Meteorology.

\title{
THE ACTIVITIES OF DONBAS ZEMSTVO DURING THE TIMES OF EMERGENCY OF THE FIRST WORLD WAR
}

Abstract: The role, forms and methods of local institutions activity in the organization of aid to the front, acts of charity, support for refugees and children are studied in the article for the first time in the modern history of Donbas.

The Bakhmut county zemstvo organized clothes, shoes, underwear sewing for soldiers and collection of food parcels with the calling in the rural community, students and intellectuals.

Festivals, concerts and performances became one of the forms of charity. The Bakhmut county zemstvo took care of the wounded, disabled, orphans, developed measures of employment and social protection.

The war caused the revival of the Ukrainian national idea among Zemstvo's population, including the form of the establishment of reading rooms in the rural huts by "Prosvita" society.

Key words: zemstvo, aid, soldier, war.

Language: Ukrainian

Citation: Tatarinov SI (2015) THE ACTIVITIES OF DONBAS ZEMSTVO DURING THE TIMES OF EMERGENCY OF THE FIRST WORLD WAR. ISJ Theoretical \& Applied Science 01 (21): 55-63. doi: http://dx.doi.org/10.15863/TAS.2015.01.21.9

\section{ДЕЯТЕЛЬНОСТЬ ЗЕМСТВА ДОНБАССА В ПЕРИД ЧРЕЗВЫЧАЙНОГО ПОЛОЖЕНИЯ 1-Й МИРОВОЙ ВОЙНЫ}

Аннотация: В статье впервые в истории изучения новейшей истории Донбасса рассматриваются роль, формы и методы деятельности земских учреждений по организации помощии фронту, организации благотворительных акицй, поддержке беженцев и детей.

Бахмутское уездное земство организовало пошив одежды, обуви, белья солдатам, сбор продуктовых посылок, привлекло к этому сельские общцины, икольников, интеллигенциюю.

Одной из форм благотворительности стали разнообразные праздники, концерты, спектакли.

Проявлялась забота о раненых, инвалидах, сиротах, разрабатывались меры их трудоустройства и соицальной защчиты.

Война вызвала в среде земцев возрождение украинской нацииональной идеи в форме создания сельских хат-читален Общества «Просвита».

Ключевые слова: земство, помощьь, солдат, война.

\section{ДІЯЛЬНІСТЬ ЗЕМСТВА ДОНБАСУ В ПЕРІОД НАДЗВИЧАЙНОГО СТАНУ 1-ї СВІТОВОЇ ВІЙНИ}

У статті вперше в історії вивчення новітньої історії Донбасу розглядаються роль, форми $і$ методи діяльності земських установ з організації допомоги фронту, організації благодійних акцій, підтримки біженциів та дітей.

Бахмутське повітове земство організувало пошиття одягу, взуття, білизни солдатам, збір продуктових посилок, привернуло до изього сільські громади, иколярів, інтелігенцію.

Однією з форм благодійнищтва стали різноманітні свята, концерти, спектаклі.

Проявлялася турбота про поранених, інвалідів, сиріт, розроблялися заходи їх працевлаштування та соиіального захисту. 
Війна викликала в середовищі земщів відродження украӥнської національної ідеї у формі створення сільських хат-читалень Товариства «Просвіта».

Ключові слова: земство, допомога, солдат, війна.

У серпні 2014 р. світ, Свропа, Україна відмітили 100-річчя початку 1-ої Світової війни, яка охопила усю Земну кулю, забрала життя десятків мільйонів людей, зруйнувала імперії Габсбургів, Романових, викликала хвилю руйнівних революцій.

У сучасному глобалізованому світі важливо знати не лише загальні наслідки таких глобальних військових конфліктів, але і їх вплив на світосприйняття маленької людини, провінції.

Тому події в Бахмутському повіті-серці індустріального Донбасу важливі своїм як позитивним, так і негативним досвідом.

Багато що 3 досвіду земських установ в період 1-ої Світової війни знайшло своє втілення в діяльності сучасного українського суспільства в зоні Антитерористичної операції в Донбасі, діяльності волонтерів і місцевих органів самоврядування.

Початок 1-ої Світової війни, як відомо, по усій Росії супроводжувалося хресними ходами, молебнями за перемогу над "тевтонами", гучною державною пропагандою.

Вдень і вночі 23 липня 1914 р. в Бахмуті відбулися монархічні безлади, були розбиті вітрини, повалені стовпи ліхтарів, пошкоджено майно електричної станції "Сіменс і Гальске" на 1060 руб. (там працювали німці-інженери). Дума відмовилася відшкодувати збитки [1].

Наступний сплеск "патріотичних почуттів" бахмутських міщан пов'язаний 3 подіями в березні 1915 році.

9 березня 1915 р. у Бахмуті була отримана телеграма, що фортеця Перемишль узята російською армією, «утром город украсился флагами...на площади возле собора был отслужен благодарственный молебен...доблестному воинству, вечной памяти воинам. На молебне присутствовали начальствующие лица, служащие правительственных и земских учреждений, учащиеся всех учебных заведений ... со своими оркестрами, масса народу, уездный предводитель дворянства К. И Карпов провозгласил «ура» нашему доблестному воинству. Слова его были покрыты громовым «ура». Оркестры заиграли гимн под несмолкаемые крики «ура» многочисленной публики» [2].

Бахмут пережив три мобілізації: першу в липні 1914 р. - з'явилися три тисячі людей, другу, і третю. У перший день мобілізації призначений на 23 листопада 1914 р. "з'явилися навіть ті люди, які не підлягали набору в ряди армії, що працюють на копальнях і заводах Донецького басейну. Більшість молодий, міцний народ"[3].
У с. Камишувасі при першій мобілізації покликаний разом 3 нижніми чинами земський начальник О. Г. Лисенков в чині підпоручика. На проводи начальника було зібрано допомозі в Червоний хрест: 289 теплих сорочок, 115 теплих кальсонів, 83 тонких сорочок, 161 тонких кальсонів, 9 простирадл, грошима 398руб. [4].

19 квітня 1915 року Положенням Ради Міністрів встановлений військовий податок 3 осіб, звільнених від військової повинності.

Військовому податку підлягали: зараховані до ополчення першого або другого розряду; звільнені від військової повинності; звільнені раніше терміну служби; іноземці чоловічої статі, що вступили в російське підданство, у віці 30 років, зараховані до ополчення 1 і 2 розряди; що не підлягають призову за досягненням ними 34 років.

Податок становив : при річному доході до тисячі руб. - 6 руб. в рік. При доході понад 1000 руб.- 25 руб. в рік. При доході до 10 тис руб. - 50 руб. в рік. При доході до 20 тис. руб. - 100 руб. в рік. При доході понад 20 тис. руб. - 200 руб. в рік. [5].

Серед перших військових заходів уряду був "сухий закон". Бахмутскою земською управою на підставі постанови чергових земських зборів 1914 p. було подане клопотання про безумовну заборону продажу казенного вина в Бахмутському повіті назавжди. [6].

У Бахмуті були закриті казенні винні крамниці. У повіті пишно розцвіло самогоноваріння і вживання отруйних спиртових рідин. Селяни ящиками купували "політуру". Поширилася торгівля різними одурманюючими "квасами", "спотикачами", "ханжами". Увійшов до вживання "денатурат" (забарвлений спирт для розтирання), пляшка доходила в ціні до 4-х руб. [5].

Головою Бахмутського комітету Всеросійського земського союзу допомоги хворим і пораненим воїнам Н.В. Рутченко була отримана телеграма 3 губернського комітету про розгортання в Бахмутському повіті ліжок : "Бажане розгортання великих госпіталів в 100300 ліжок при станції залізниці. Після огляду місцевих будівель було визнано за можливе, відкрити шпиталі в 1-й і 2-й жіночих гімназіях, міському жіночому училищі Олександрівському і казенному винному складі"[7-9].

У Бахмуті був створений Комітет 35 гласних, виділено до 50 тис. руб. на потреби шпиталів, розгорнуто 260 ліжок в шпиталях і 40 ліжок в міській лікарні. У земських школах шили 
білизну і в'язали речі пораненим, на що було потрібно 1000 руб. [10].

Газета "Бахмутське життя" надрукувала вдячність поранених солдатів за лікування в шпиталі при 2-й жіночій гімназії.

Земські діячі, інтелігенція, священики i селяни вносили пожертвування для солдатів на фронті. Про це свідчать публікації в "Народній газеті", яка наводила такі приклади, як передачу бойового коня священиком Павленко 3 c. Луганське, збір коштів в с. Рутченково (Юзівка) священиком С. Кириловим [11].

У селищі Авдіївка в грудні 1914 р священик о. Іваницький зібрав на допомогу воїнам різних продуктів104 пуди[12].

3 c. Старо-Михайлівки відділенням Товариства Червоного Хреста 5 лютого 1915 р. було відправлено до Бахмуту 12 рушників, 4 сорочки, 15 шматків полотна і 101 руб. 3 усіх цих грошей: поступило членських внесків 16 руб.;по книжкам поранених і хворих 22 руб.; з спектакля 7,95 руб., « кухлями» 31-го січня від населення 41руб.. «С каким старанием, трогательностью деревенская женщина подает в четверо сложенный беленький «шматок полотна», ибо слышит призыв «помощь нужна!», руки дрожат, на глазах слезы... нет человека в деревне, мысли... прикованы к сыну, мужу, отцу, дяде, к «гарному сусиду»[13].

, У цьому селі 5 березня 1915 р. позиковоощадне Товариство послало в діючу армію 38 фунтів тютюну, 300 листів паперу, 13 фунтів печива і 161 коробку сірників. 12 квітня 1915 р. отримало повідомлення 3 вдячністю від командира 28-го Донського козачого полку.[4].

У грудні 1914 р. в с. Калинове був відкритий відділ Червоного Хреста, записалися майже усі місцеві інтелігенти щоб збільшити ще приплив пожертвувань, члени комітету придбали "живий ліхтар" «концерты, данные местными любителями пения, прошли превосходно...на сбор пожертвований в пользу Красного Креста грех было жаловаться»[13].

«У кінці листопада 1914 p. учениці Юзівського училища Милославського зшили 94 кисети, хлопчики зібрали тютюн, сірники i цигарковий папір для Бахмутського комітету Червоного Хреста. У кожен кисет була вкладена записка з назвою училища і ім'ям учня. На ім'я учнів приходили листи від солдатів, наприклад: «Дорогой юноша Митя! Получил я от тебя подарок, за который премного благодарю и желаю тебе здравия и успехов в твоем учении. С почетом, Вадим Михайлович Воронов 2-й батареи, 71-й артиллерийской бригады»[14].

В с. Григорівка (Рутченково-Юзівка) з 13 грудня 1914 р. булол відкрито відділ Бахмутського Комітету Червоного Хреста, «за полтора месяца поступило наличными деньгами
779 руб., «вещами не менее как на эту сумму» $[15]$.

3 села Луганське в «Народну газету» писали: «с тех пор, как наши братья ушли на защиту своей родины, мы неустанно следим за событиями войны... не перестаем думать о наших героях - солдатах и делаем все возможное, чтобы улучшить их положение, нашими крестьянами было собрано 116 пудов сухарей и со ст. Роты Екат. жел. дороги отправлено в действующую армию. Местная молодежь устроила спектакль, а затем концерт в пользу раненых и больных воинов»[14].

У листопаді 1914 р. «по отзыву сборщиков отношение народа весьма сочувственно..., невольно приходишь к убеждению, что ... сильна любовь к родине и готовность прийти на помощь страдающему человеку.... Входишь в хату и просишь пожертвовать на благое дело. Крестьянин или крестьянка опускают в кружку свое пожертвование, крестятся... У кого есть несколько копеек мелочью - виновато извиняются, что не могут пожертвовать больше. Таких успокаиваешь и утешаешь тем, что всякая жертва как бы она ни была мала, но будучи дана от чистого сердца - будет принята Богом»[15].

Службовці Бахмутської земської управи щорічно організовували різдвяну ялинку, в 1915 p. зібрані 80 руб. передали М. М. Бараннікову для придбання 40 фунтів тютюну, 16 пакетів 3 повним комплектом теплої білизни, милом, поштовим папером. Усе це переслали через Управління залізниці на фронт і отримали листи 3 вдячностями від солдатів [16].

Комітет Щербинівської копальні відправив до армії до різдва 1915 р. два вагони подарунків для нижніх чинів i офіцерів. $\mathrm{y}$ зборі пожертвувань брали участь службовці копалень Щербинівського, Нелепівського, Микитівського Товариств, Товарисство оренди Ауэрбаха, копалень №8,1,5 Південно-російського Товариства в Горлівці, Государево-Байракського, жителі навколишніх сіл i колоній. Було відправлено біля 3500 різних теплих речей, 65 пудів сала і ковбаси, 45 пудів тютюну, 7 пудів чаю, 70 пудів цукру, 60 пудів окремих подарунків, 240 пар чобіт, сухарі, мило, свічки, всього 700 пудів, на суму 9000 руб.[17].

«Народна газета у березні 1915 p. Звернулася до читачів: «поможем солдатам встретить Пасху. Пожертвования принимаются уездным комитетом Всероссийского земского союза в Бахмутской уездной земской управе. Для посылки в армию желательно: белые пшеничные сухари, сложенные в мешки, лучше в ящики, не более трех пудов каждый, сорочки, кальсоны, свечи, чай, сахар, соль, кисеты с табаком, мыло, нитки, иголки, гребешки чистые, куски сала, конфеты, орехи, семечки, можно так же открытки 
со своими адресами. Весь комплект заворачивается в полотно и зашивается. Эта обертка послужит солдатам портянками»[5].

Новоселівське відділення опіки імені графа Келлера повідомляло про добродійні акції: пожертвувань поступило 22,5 руб.; від лотереїалегрі 33,4 руб.; від продажу пожертвуваного ячміню 1 руб.;збору з спектаклю 31,6 руб.; від Бахмутської управи 100 руб. Всього 188,7 руб. Витрата цих коштів : поштові витрати 1,5 руб.; урна для квитків лотереї 0,3 руб.; для сімейств мобілізовані придбано "сорго" і "чумиза" на 28,6. руб.; куплено ячміню для посіву десятини землі на користь відділення опіки 2,7 руб.; сплачено за посів десятини землі 3 руб.; видано 34 родинам мобілізованих і бідним 137 руб. [18].

49 - е Катеринославське губернське земське зібрання в квітні 1915 р. обговорило питання, викликані війною: допомога постраждалому населенню Польщі, Галіції, Бельгії, Сербії і Чорногорії; забезпечення родин нижніх чинів, узятих на війну; увічнення пам'яті загиблих на війні; піклування про покалічених воїнів; захист населення від епідемій холери, чуми, сибірської виразки, тифу; про застосування праці військовополонених на спорудженні земських доріг [15].

У Бахмуті "люди цікавилися останніми новинами з фронту, постійно збирали допомогу". «Буквально каждую неделю, общество Красного Креста, церковные служащие, ходили в городе, по близлежащим хуторам, селам собирая деньги - так называемый «кружечный сбор» и прочие пожертвования на фронт».

Були введені обов'язкові поставки ремісниками-кустарями взуття для армії на початку 1915 р.: "усім шевцям шити по дві пари взуття в тиждень, інакше штраф 300 руб., 3 місяці в'язниці". На початок 1915 р.. було прийнято 380 пар взуття [19].

Військова рада 23 липня 1915 р. збільшила ціни "на чоботи і білизну, довільного зразка, що придбалися від новобранців і ополченців які закликатимуться протягом 1915 г". Пара чобіт до 9 руб., натільна сорочка 80 коп. спідні брюки 65 коп. пара онуч 20 коп., утиральник 28 коп.[28].

Армія потребувала пошиття натільної білизни. Бахмутська земська управа виплатила авансом за пошиття в училищах білизни для солдатів[21].

Училищами було виготовлено сорочок 662 , кальсонів 540, панчох 19 пар, простирадл 16, рукавичок 27, наволочок 4, кисетів 57, напульсників 19, шарфів 26, онуч 55, зібрано ниток 1 пасма, 2 ф. білих, махорки 128 пачок, цигарок 9 пачок, турецького тютюну $1 / 8$ ф., хусток 26 шт., емальованих кухлів 1 шт., цукру 1 ф., шоломів 6 шт., халатів 1., полотна 1 шматок в
3 аршини, вата 1,1/4 ф., навушників 2 шт., сухарів 1 пуд., свиного сала1 пуд, насіння 5 пудів[21].

Широко практикувалася відправка земських делегацій на фронт 3 подарунками. Центральні російські газети повідомили, що «в Москву вернулся с театра военных действий бывший член городской управы С.В. Челноков. Он пробыл на передовых позициях около недели, видел работу земских сан. отрядов и отрядов Красного Креста... Поражаешься откуда берутся силы...В чем же нуждается армия? Мне пришлось видеть на позициях две бани. Трудно передать счастье людей, получивших свою очередь попасть в баню. Дети не могут так радоваться, как радовались наши серые герои, ... кричать надо, что бы наши обыватели откликнулись и послали в армию по возможности больше походного белья и штанов. Какое счастье будет для людей, вымывшихся в бане, надеть на себя чистую сорочку и получить новые штаны»[22].

13 березня 1915 р. була закінчена у Бахмуті погрузка ящиків з подарунками, на другій день ці подарунки з Бахмуту прибули у Катеринослав. «Получив пропуски, билеты и документы на отправляемый груз, из Екатеринослава выехало 18 лиц, сопровождающих подарки из Бахмута. По прибытию они увидели картину из серых людей, которые бродили вдоль эшелонов в поисках хлеба или в попытках что-то продать. Пленные с Карпат ходили в отрепках, из Перемышля были больно хорошо одеты... Чехи, поляки и русины с радостью отвечали, кто они и вступали в разговор. Общее впечатление о пленных осталось такое, что никто из них не страдает нравственно, что почти все довольны своим положением, и глядя на них, не верится, что эти люди могли когда-либо составлять грозную силу, способную на упорное сражение».

Делегация прибыла в Радивиллов. «Уполномоченных на этой станции собралось с разных концов России около 80 человек. Далеевсех отправили в Заболотце, куда прибыли утром. Здесь должна быть перегрузка в австрийские вагоны, так как дальше идет узкая колея. Кое-как удалось отправиться из Заболотце. Утром прибыли на громадный львовский вокзал. После небольшой экскурсии околицами львовского вокзала приехали в город Станислав, который показался очень приветливым и уютным. И к вечеру 24 марта делегация Бахмута представилась полковому командиру. Во время ужина были розданы подарки солдатам, которые шли в окопы. Окопы представляли собою канаву глубиной аршина полтора с небольшими, укрытыми соломою землянками, в которых спят наши братья - солдаты. Солдаты расспрашивали у гостей, что делается дома, получают ли семьи пособия, и вспоминали про родные края. 
Рассказывали, что зимой делалось, как приходилось по 7 суток в мокрых окопах бессменно сидеть. Как приходилось в стужу делиться шинелью с раненым врагом или куском хлеба».

26 березня група уповноважених, зібравши листи від солдатів рідним, відправилася назад додому в Бахмут.

Міський Голова В. І. Першин організував поїздку делегації з подарунками на фронт в 1916 p. в частину сина-капітана Максима Першина.

У "Народній газеті" було піднято питання про те, що i як пересилати росіянам військовополоненим -"посылки для военнопленных Германии сдаются в почтовые учреждения, каждая не должна весить более 12фунтов,разрешается пересылать сахар, чай, папиросы, медикаменты в сухом виде и новую одежду. Не разрешатся сухари всякого рода, сало, икру, предметы роскоши, предметы в упаковке из металла. На посылках пишется адрес на русском и французском языках, должно быть указано: название государства, город, полк или лагерь, в котором находится военнопленный, часть, имя, отчество, фамилия военнопленного и его чин» [20].

Великий розмах отримав рух по виготовленню пов'язок від отруйного газу Іприту, який застосували німці на фронті:"користь була приголомшливою, оскільки ці самі пов'язки. Були визнані кращим засобом проти "нового способу німецької війни". Комітетом Бахмутського Всеросійського земського союзу на засіданні 9 липня 1915 р. було асигновано 600 руб. на пошиття респіраторів. У Бахмуті на виготовлення пов'язок відділом Червоного хреста було виділено 400 руб. «І пов'язки вже шиються місцевими пані. Їх шиття надзвичайне просте i шити їх можуть навіть діти. Охочі шити респіратори можуть звернутися в редакцію «Народної газети» і отримати зразки пов'язки і викрійки» [12].

Велику популярність в Бахмуті і повіті отримали різні добродійні спектаклі і виступи для поранених солдатів на лікуванні в шпиталях. Часто виступали учні. «Это поддерживает настроение раненых солдат, и дает искру добра и счастья, отвлечения от ужаса войны».

26 грудня 1914 р. у Юзівці в приміщенні залізничної школи був влаштований спектакль "Назар Стодоля". Збір склав 350 руб. Половина збору була передана місцевому Відділенню Залізничного Комітету з надання допомоги сім'ям запасних [20].

Музична громадськість Бахмуту влаштовувала в літньому театрі Чепурковського концерти для збора коштів "сім'ям покликаних на війну" (1915р.), "на користь сімей запасних" (1916 р.), "для потерпілих від повені в місті" (березень 1917 р.). 30 травня 1916 р. Опікунська Рада Соборної церкви організувала в сквері гуляння 3 оркестром 25-го запасного полку. Зібрані гроші були передані "сім'ям запасних, узятих в армію".

На афіше 14 березня 1917 р., надрукованою на величезному листі яскраво червоного кольору в друкарні Гріліхеса, була програма концерту : твори "Спіть, орли бойові" Ружицького, кантата "Русь свята йде на війну", арія 3 опери "Князь Ігор" у виконанні Михайла Костянтинова (гімназиста - восьмикласника). Б. Яковлєв виконував частівки "Що ви, німці, голови повісили?", куплети, декламація. У січні 1915 р. в газеті "Бахмутське життя" було опубліковано звернення: «нас просят обратить внимание на отсутствие в библиотеке им. Гоголя карты военных действий, что представляет большое неудобство для читателей, вынужденных прибегать к помощи энциклопедического словаря».

3 весни 1915 р. гостро постало питання забезпечення нормальних польових робіт в селах повіту, який годував не лише армію, але і півмільйонне населення краю.

У селі Троїцькому до Позиково-ощадного товариства було прийнято звернення: «...прошлогодний неурожай и война внесли в нашу местность большую нужду. Нужда отражается где один, два, три работника находятся на войне...Не за горами у нас весна, с охотой мы собираем борону, чиним сбрую, стараемся купить хороших семян. Семьи бедных семейств, хозяева которых любуются государственною бороною, ружьем, являются горькой противоположностью...Правление Троицкого попечительства общества помощи солдатам и их семьям, просит вступить в его среду благотворителей, для чего нужно внести не менее 500руб. единовременно» [5].

«Народна газета» писала, что «поля в уезде были засеяны, большей частью этот труд был выполнен крестьянками. В это время, когда мужья крестьянок призваны на фронт, крестьянки играют большую роль в деревнях, так как вся работа ложилась на их плечи...Не смотря на все препятствия нужно отметить тот факт, что поля ... засеяны и большей частью этот труд был выполнен крестьянскими бабами, которые работали в очень многих местах, все гуртом. Заканчиваем посевы яровых. Думали, что не справимся, но справились не хуже мужчин. Некоторые женщины работали в мужских костюмах, что бы это было сподручнее». [23].

У с. Старо-Михайлівка були улаштовані ясла, розраховані на 50 дітей, вони повинні були тривати на протязі липня і серпня. На устрій ясел Бахмутська земська управа виділила 380 руб. 
Ясла дозволяли жінкам спокійно працювати в полі.

У 1915 р. почалася заготівля провіанту для кавалерії і кінської тяги в армії: «Весь обращаемый в продажу овес нужен нашим войскам и повсеместно будет скупаться уездными земствами по назначенной казенной цене. Для продажи овса мелких хозяевам лучше соединять свои запасы и поставлять их от общества или через кредитные и $\mathrm{c} \backslash \mathrm{x}$ товарищества, земские управы могут сами устраивать склады зерна при станциях. В случае отказа от добровольной продажи...будет применяться реквизиция с уплатой на $15 \%$ ниже добровольных цен. Основная цена пуда 1руб. 12 коп.» [24].

Фактично відбувалося примусове вилучення фуражу у селян, коней, що призвело до різкого падіння сільського господарства до кінця 1916 р.

Загальноросійським

"Романовским комітетом" було задовільнено 52 клопотання земських установ, добродійних організацій про відпуск допомоги на різні види піклування селянських сиріт, дітей запасних, ополченців і ополченців сільського стану на суму 102555 руб., у тому числі 40075 руб. відомствам повітів. Земства почали влаштувати нові сирітські притулки або розширяти існуючі, організувати харчування і постачання одягу школярам дітям запасних і ополченців, засновувати стипендії для сиріт в ремісничих, сільськогосподарських i інших нижчих учбових закладах[25].

Гостро встала проблема навчання в Бахмутському повіті дітей біженців.

Напередодні нового 1915 -16 навчального року голова комісії директорів учбових закладів Бахмуту директор Реального училища М. Р. Степанов повідомив, що «дети беженцев принимались во все учебные заведения сверх комплекта без различия вероисповедания. С ходатайствами нужно было обращаться к начальникам соответствующих учебных заведений, по низшим начальным училищем к инспекторам народных училищ»[25].

Земство шукало для сиріт «пути решения в виде устройства приюта колонии для сирот может быть открыто при Каменском сельскохозяйственном училище, цель его в подготовке опытных рабочих по садоводству и огородничеству, пчеловодству, шелководству, скотоводстве, столярному и кузнечному ремеслу. ..Требуются специальные затраты и расходы на приспособление указанных учреждений к устройству приюта колонии, эти расходы слишком ничтожны сомнений той целью, на какую они предназначаются»[16].

«Приют-колония, подготовляя садовых и огородных рабочих, тем самым будет удовлетворять непосредственно нужды частновладельческих хозяев. Открывая приютколонию для сирот и раненых досрочных воинов, Бахмутское уездное земство в своем высокопатриотическом выступлении сразу проявит весьма сочувственное отношение к тому призыву. Подготовляя в приют-колонии опытных садовых и огородных рабочих, Бахмутское уездное земство примет меры к удовлетворению назревшей нужды наших частновладельческих хозяйств в указанных лицах» - наполягав земський санітарний лікар Г. Фіалковський[5].

Бахмутським відділенням допомоги біженцям восени 1915 р. розіслано у Волосні правління доручення: зібрати квитанції у усіх біженців, що здали продукти i худобу ліквідаційним комісіям Волинської губернії 3 видачею ним тимчасових розписок в прийнятті цих квитанцій; передати ці квитанції в Комітет повіту, списки повинні мати ім'я, по батькові і прізвище кожного власника наданої квитанції, місце постійного його проживання до виїзду 3 Волинської губернії, місце проживання нині, суму винагороди, що належить за продукти $\mathrm{i}$ худобу [20].

Зростання цін на продукти харчування, перебої з їх постачанням в повіт стали першими вісниками продовольчої катастрофи.

$$
\text { Тому земство зробило ряд }
$$
попереджувальних заходів. На засіданні Бахмутського комітету повіту із з'ясування потреб населення в предметах першої необхідності були розглянуті наступні питання: "про кількість народонаселення в повіті за відомостями, наявними в управі, складає 565 тисяч; "про кількість наявних в повіті запасів продуктів першої необхідності, на який час досить цих запасів для населення" - не міг бути розглянутий за відсутністю статистичного матеріалу;"про рід і кількість продуктів першої необхідності, в яких відчувається недолік" передбачалася нестача на зерно, крупу, чай, масло різне, свічки, мило, обгортковий папір :" про ціни на продукти першої необхідності і про їх нормування" - комітет встановив граничні ціни на цукор, чай, каву, свічки, сірники, мило, рис, крупу, папір, гас; "про способи забезпечення населення повіту продуктами першої необхідності у разі нестачі шляхом закупівель" комітет висловився за швидке об'єднання закупівель Товариствами по районах в цілях економії; "про фінансову сторону" - визнали необхідність фінансування; "про положення 3 підвезенням продуктів першої необхідності в повіт" - комітет визнав швидке врегулювання залізничних перевезень вантажів; " про кількість продуктів першої необхідності, які можна вивезти 3 повіту як надлишки, без збитку для повіту" - вивезти $з$ повіту можна сіль, борошно при достатньому ввезенні зерна в повіт [16]. 
У Бахмутський комітет Всеросійського земського союзу з постачання армії з 25 липня. 1915 р.. увійшли М.В. Рутченко - голова земської управи, Стеклер, В. К. Корчиць, І.В. Піддубний, I. I Погорелов, М.В. Пестерев, М.I. Новгородцев, М. Р. Степанов, Г. І. Желинський, В. К. Червинський. На Виконавський комітет 35 осіб була покладена робота по мобілізації місцевих фабрик, заводів, ремісників, для їх придатності у військових цілях [20].

Війна, переміщення величезних мас населення, біженці - усе це було зв'язано із зростанням інфекційних хвороб, загрозою епідемій.

У повіті населення оповіщалося про застережні заходи проти холери, була оголошена інструкція 3 мінімальними вимогами для профілактики хвороб.

«Отовсюду тревожные слухи о грозящих эпидемических заболеваниях. Всюду принимаются меры предупреждения на случай появления холеры. По соседству каменноугольные рудники так почистили, что некоторые хозяева рудника не узнают рудников так как, они, рудники, приняли «не нормальный» вид»- вказували земці.

«В Лисичанске имеется базарная улица, грязнее которой во всем селе днем с огнем не найти... такая, что невозможно дышать, грязь классическая, непроходимая. Базар от навоза в хорошую погоду один раз в неделю, а в плохую и в месяц не одного раза» [26].

9 червня 1915 р. членами Санітарної опіки було оглянуто селище Гришино, «обе базарные площади (старая и новая) загрязнены вследствие неимения ни одной из них ретирад (санузлов), загрязненная водосточная канава». Было решено построить уборные, почистить канаву, заняться гигиеной труда на местных мясных, хлебных лавок, «так как там не был о обнаружено ни одной выгребной ямы».

Принято решение замостить базарную площадь камнем, «дабы избежать неровностей и грязи...запретить местным жителям выпускать домашний скот на улицы, держать его только во дворах и в чистоте»[27].

У Гришино була видана постанова, в якій вказувалося облаштувати базар санітарним вузлом, влаштувати водостічну канаву для боротьби з нечистотами.

В період 1-ої Світової війни в повіті працювало 27 лікарів, 39 шкільних фельдшерів, 23 акушерки, 14 військових фельдшерів, 5 фармацевтів. "Запасних лікарів" було 2, фельдшерів - 3, фельдшерів-акушерів - 3 .

9 липня 1915 р. в Бахмутській земській управі відбулася нарада власників дрібних шахт Щербинівського i Микитівського району про організацію медичної допомоги робітником.
Нарада винесла ухвалу: зберегти Микитівську спільну лікарню дрібних шахт і подальше іiі устаткування; за утруднень при зборі членами господарських комітетів сум на утримання таких спільних лікарень, просити управу повіту клопотати перед губернатором про доручення цих зборів офіційній установі (Губернській по страхових справах присутності, лікарському відділенню губернського правління); визнати ці збори обов'язковими; найближчим часом окрім Микитівської лікарні відкрити подібні лікарні в найманих приміщеннях в селищі біля Щербинівської копальні, на ПівденноМикитівській копальні; скликати на місцях наради шахтовласників по районах для з'ясування деталей організації лікарень, кошторисів на утримання і устаткування; просити взяти участь в нарадах чинів гірського нагляду[6].

«Во всех учреждениях раненым и увечным воинам будут предоставляться низшие служительские должности» - повідомляло земство повіту.

У Звіті Селідівського Волосного опікування про поранених і сім'ях солдатів 31 серпня 1914 р. по 1 квітня 1915 р. показані прихід вугілля : від Геккера- 1000 п., Белинського- 200 п., Прохиля200 п. Муки пшеничної- 199 пудів., холсту- 179 аршин, сорочок - 9, кальсонів - 9, платков- 15, рушників- 15. Борошно видавалося по півпуда на дорослого і по 10 фунтів на дітей в місяць (незаможним). Вугілля видавалося по 20 пудів в місяць на сім'ю. Гроші видавалися тільки вкрай нужденним сім'ям перед святами Різдва і Паскою. Полотно, сорочки і інше були відправлені до Бахмутського Червоного Хреста [28].

У зв'язку з тим, що з шпіталів виписувалося значне число воїнів, які отримали каліцтва втрату рук, ніг, "внаслідок цього втратили здатність до роботи. Всеросійський Земський союз і Союз міст «влаштували в місті Харків по Ветеринарній вулиці в будинку Обласну Протезно-ортопедичну майстерню, що має мету заготовляти i забезпечувати воїнів штучними кінцівками і ортопедичними апаратами" [29].

Гостро стояло питання використання робочої сили військовополонених німців i австрійців.

Праця полонених використовувалася на здобичі каменю, мощенні доріг, спорудженні гребель, чищенні ставків, роботах проти яруг. Через нестачу робітників працю полонених використовували на вогнетривких заводах Часів Яру [4].

У 1917 р. в селі Бантишево, Бахмутського повіту застосовувалася праця німецьких військовополонених. Місцеві (наймити) селяни були невдоволені, тому що тим самим у них забирали роботу. 
Таємний радник В. І. Карпов вніс "прожект" про використання праці полонених і послав копію голові Союзу гірничопромисловців Півдня Росії фон Дітмару в Харків.

Гласний, власник вугільної шахти В. П. Пестерев запропонував використати полонених австрійців до технічного дослідження водних шляхів по руслах Юзівського району, але пропозиція не зустріла співчуття серед гласних і більшістю голосів збори відхилили пропозицію[30].

Управою повіту було висунуто клопотання про з'єднання по воді Юзівського району 3 Маріуполем, з'єднанні каналами річок Сіверського Дінця, Казенного Торця, та ін., про врегулювання річок Бахмут, Лугань, і Кривого Торця до Кальміусу для з'єднання цих річок 3 Маріупольським портом із застосуванням для цих робіт праці військовополонених.

Гласний В. П. Петров запропонував притягнути полонених австрійців до технічного дослідження перерахованих водних шляхів, але його пропозиція «не встретило сочувствия» среди гласных и большинством голосов собрание отклонило это предложение».Але повітове зібрання вирішило «ассигновать из уездного сбора на сооружения в уезде 75000 руб.».

В період 1-ої Світової війни почався процес відродження української свідомості на Катеринославщині. Свідоцтвом цього став випуск першого "Українського календаря" в 1916 р.. Він містив методичні і правові вказівки відносно відкриття хат-читалень "Просвіти".

Народні бібліотеки і читальні засновували 3 дозволу губернатора. Щоб отримати дозвіл на відкриття потрібно було подати губернаторові відповідне прохання, до якого необхідно було подавати дві гербових марки по 75 коп. підписку того, хто бере на себе відповідальність за створення бібліотеки, щоб в справах бібліотеки брала участь місцева громада, яка створювала бібліотечні Товариства. Вони розділялися на два типи: перші користувалися усіма юридичними правами, другі не мали цих прав.

Для того, щоб заснувати Товариство 3 юридичними правами потрібно було подати зразок Статуту, який розглядався "Губернським у справах про Товариства Присутствієм". Вимоги до статуту: назва Товариства, його мета, район і напрями його діяльності, прізвища, ім'я, по батькові, станові звання і адреси тих, хто засновує його; розмір членських внесків i порядок їх виплати; коли і як скликаються загальні збори членів і питання компетенції; як ведеться звітність і механізм внесення змін в статут. Заява про основу Товариства 3 юридичними правами потрібно було подавати губернаторові з підписами засновників. До заяви слід було додавати нотаріальне посвідчення про правоздатність засновників; нотаріальне посвідчення їх підписів; два екземпляри завіреного ними зразка Статуту; гроші на друкування оголошень про заснування Товариства. Якщо створення Товариства дозволялося, його записували в реєстр, в Сенатських і Губернських "Відомостях".

Від Товариства без юридичних прав не потрібно було прикладати Статут. Губернатор сам затверджував його або передавав заяву на розгляд "Губернського у справах про Товариства Присутствія", В заяві потрібно було відмічати: мета роботи; назва; прізвища, імена, по батькові, стани, звання і адреси засновників; територію діяльності; порядок вступу і вибування членів.

Якщо протягом 2 - $\mathrm{x}$ тижнів від представлення заяви і передачі губернатором в Присутствіє не було відмовлено в затвердженні Товариства, то воно могло починати свою діяльність. Якщо прохання не було вирішене, "Присутністствіє" вказувало причини не затвердження. За роз'ясненням різних питань в справі заснцвання бібліотек потрібно було звертатися до українських Товариств "Просвіта" і Харківському товариству писемності.

Земські діячі повіту не лише працювали для фронту, але і займалися іноді політиканством.

Абсолютно приголомшуючою по історичному неуцтву i ура-патріотизму була доповідь земству відставного штаб-ротмістра Миколи Ілліча Ларіна, у якій перемішалися "хрестові походи проти турок", Олександр Третій, Бісмарк, "грубий німецький лицар" Вільгельм II. Ларін закликав ліквідувати німецьке засилля, перейменувати німецькі колонії Донбасу і дати їм російські назви, змінити роботу німецьких колоністських шкіл.

I це при тому, що у вищих ешелонах Російської імперії, серед генералітету і чиновництва було повно німців.

Після евакуації до Бахмуту, ВолодимирВолинської гімназії і розміщення її в приміщенні Реального училища, виникає Союз учнів гімназій-українців. 3 його лав вийшли відомі національні українські діячі Михайло і Микола Малашки.

Висновок. Вивчення діяльності земських органів самоврядування, провінційного суспільства Донбасу в період 1-ої Світової війни вказує на багато аналогій 3 сьогоднішніми подіями на Сході України: добродійність українського населення бійцям АТО, діяльність добровольців-волонтерів від різних соціальних груп (дрібний і середній бізнес, інтелігенція, молодь, пенсіонери, робітники, селяни) по наданню допомоги українській армії, участь нових організацій громадянського суспільства, що народжуються, в зміцненні тилу, мобілізація усіх ресурсів для військово-політичного 


\section{References:}

1. Brovkin LV, Tatarinov SI, Shatalin AV (2007) Istoriya pravookhranitel'nykh organov Bakhmuta - Artemovska /L.V.Brovni// Artemovsk, pp. 86.

2. Tatarinov SY, Tutova NO (2008) Narisi ístorií samovryaduvannya u Bakhmutí ta povítí /S.Y.Tatarinov// - Artemívs'k, - 234.

3. (1915) Narodnaya gazeta (daleye NG), №10.

4. (1915) «Narodnaya Gazeta Bakhmutskogo zemstva» №18.

5. (1915) «Narodnaya Gazeta Bakhmutskogo zemstva» №30.

6. (1915) «Narodnaya Gazeta Bakhmutskogo zemstva» №16.

7. (1915) Otchet Bakhmutskoy uyezdnoy zemskoy upravy za 1914. - Bakhmut: Tip. Val'dshteyna.

8. (1914) Zhurnaly Bakhmutskoy uyezdnoy zemskoy upravy 20-26 oktyabrya 1914. 49 zasedaniye. - Bakhmut;

9. (1915) Zhurnal chrezvychaynogo sobraniya Bakhmutskoy uyezdnoy upravy 31 marta 1915 goda. - Bakhmut.: tip. Val'dshteyna.

10. (1914) Narodnaya gazeta Bakhmutskogo zemstva.

11. Tatarinov SY, Tutova NO (2014) Pravoslavna tserkva na Donechchiní. Donets'k: Gelos-Prínt, 185.

12. (1915) «Narodnaya Gazeta Bakhmutskogo zemstva» №3.

13. (1915) «Narodnaya Gazeta Bakhmutskogo zemstva» №11.

14. (1915) «Narodnaya Gazeta Bakhmutskogo zemstva» №5.
15. (1915) «Narodnaya Gazeta Bakhmutskogo zemstva», №10.

16. (1915) «Narodnaya Gazeta Bakhmutskogo zemstva» №29.

17. (1915) «Narodnaya Gazeta Bakhmutskogo zemstva», №1.

18. (1915) «Narodnaya Gazeta Bakhmutskogo zemstva» №27.

19. (1915) «Narodnaya Gazeta Bakhmutskogo zemstva» №36.

20. (1915) «Narodnaya Gazeta Bakhmutskogo zemstva» №25.

21. (1915) «Narodnaya Gazeta Bakhmutskogo zemstva», №2.

22. Brovkin LV, Tatarinov SI, Shatalin AV (2007) Istoriya pravookhranitel'nykh organov Bakhmuta - Artemovska. Artemovsk, pp. 96.

23. (1915) «Narodnaya Gazeta Bakhmutskogo zemstva» №31.

24. (1915) «Narodnaya Gazeta Bakhmutskogo zemstva» №35.

25. (1915) «Narodnaya Gazeta Bakhmutskogo zemstva» №39.

26. (1915) «Narodnaya Gazeta Bakhmutskogo zemstva» №42.

27. Tret'yakov KM, Tatarinov SI (2011) Istoki ogneupornoy promyshlennosti Ukrainy. / K.M.Tret'yakov//. -Artemovsk, 2011, - 270.

28. (1916) Ukrainskiy kalendar' na 1916 r. Yekaterinoslav.

29. (1915) Spravochnaya kniga Yekaterinoslavskoy gubernii za 1916 god. - Yekaterinoslav.

30. Koval' RM (2005) Bagryaní zhniva revolyutsiï/ R.M.Koval'// - Kiïv: Dizayn. 